\title{
A Critique of Conservation and Management of Shore-nesting Birds
}

\author{
Jing $\mathrm{Li}^{1}$ \\ ${ }^{1}$ School of Geosciences, the University of Sydney, Sydney, Australia \\ Correspondence: Jing Li, CNTIC International Contracting \& Engineering Co., LTD. No 234, Yao Jialing Street, \\ Wuchang, Wuhan 430071, Hubei, China. Tel: 86-150-7133-7631. E-mail: jili2217@uni.sydney.edu.au
}

\author{
Received: September 10, 2012 Accepted: September 24, 2012 Online Published: November 29, 2012 \\ doi:10.5539/ijb.v5n1p46 \\ URL: http://dx.doi.org/10.5539/ijb.v5n1p46
}

\begin{abstract}
Shorebirds are usually migratory animals that regularly travel between northern and southern parts of the world. In the past few decades, damage and alteration of habitat and the potential problem of population decrease have encouraged more and more people to attach great importance of the management of shorebirds on refuges, and to preserve for both breeding and migrating species. This dissertation chiefly examines the differences between chosen measures for shorebird protection and throws light upon potential knowledge gaps when it comes to management of those creatures. As a result, active measures that can be taken to make significant improvements, for example, learn to recognize potential nesting habitat and built viewing platforms to contain eco-tourists and promote sustainable development.
\end{abstract}

Keywords: shorebirds, habitat, human disturbance, conservation

\section{Background and Aims}

Shorebirds are some of the most highly migratory creatures recognized, and they routinely travel between northern and southern lands of the earth (Brian, 2007). In just 25 years some of these species have decreased by approximately fifty to eighty percent, and in at least one species declines have been as rapid as twenty percent in recent decades (Jaensch, 2009). Prince William Sound, on the south coast of Alaska, which is expected to undergo six times increase in recreational use by 2015 (Paul \& Dan, 2003). Undoubtedly, this increase has a negative impact to the habitat of shore-nesting birds, such as black oystercatchers (Paul \& Dan, 2003). Consequently, destruction and alteration of habitat and the potential risk of population decline highlight the importance of management of shorebirds on refuges, and preserves for both breeding and migrating species (Jan, 1992).

Moreover, a number of case studies are concerned about the survival of shorebirds. A critical challenge for conservation biology is estimation of population trends (Lawton \& May, 1995), especially for species of preservation concern, where further decline might lead to extinction and management is necessary for their survival (Caughley \& Gunn, 1996). Even though birds are well considered, few long-term population data presented that separate random variable from population declines (Silke et al., 2008). In addition, difficulties in predicting trends are exacerbated for highly mobile species (Silke et al., 2008).

Therefore, this report will give a general description about how conservational investigations and researches have been taken place with respects to shore-nesting birds. Then, mainly address the differences between chosen measures and throw light upon potential knowledge gaps when it comes to management of those shorebirds, with critical review provided. In the end, put forward some practical suggestions. The two main papers in this discussion include: "Individual-based ecology of coastal birds" by Richard et al. (2009), and "The effect of human activities on migrant shorebirds: successful adaptive management" by Joanna et al. (2004).

\section{Overview of Previous Research on Shorebirds}

Research on shorebirds has undergone several decades, thus yielding monumental findings, which have exerted significant influence on the current management of shorebirds and its policy strategies. Macroscopically, most shorebird breeding ecology studies have involved particular species in a single location or have focused on species of concern, like endangered piping plovers (Charadrius melodius) (Haig \& Oring, 1985) and threatened snowy plovers (Warriner et al., 1986). However, microscopically, more recent research focuses on shorebirds nesting and post-nesting success, for example, natal dispersal of American avocets in California (Robinson \& Oring, 1997). Bowen and Kruse examined habitat use and nesting success of upland sandpipers (Bartramia 
longicuda) in south-central North Dakota (Bowen \& Kruse, 1993). Finally, Koenen demonstrated that predation and climate change reduced success of shore nests (Koenen et al., 1996). Rubega also illustrated that salinization affect shorebird reproduction unless anything possible to secure freshwater for wetlands with breeding shorebirds (Rubega et al., 1996). As a result, these studies show that habitat destruction or disturbance becomes a major threat to the survival of shore-nesting birds, regional studies are needed to develop management recommendations on a landscape scale at the same time.

The aim of the paper by Richard et al. (2009) was to conservation purposes for non-breeding shorebirds from their population size at coastal sites. The theoretical outline is individual-based ecology, in which populations are regarded as having properties (e.g. size) that originate from the characters (e.g. behavior, physiology) and contacts of their constituent individuals (Grimm \& Railsback, 2005). The link between individuals and populations is made through individual-based models that follow two key principles, emergence and fitness (Railsback, 2001). Emergence represents that behavior is not compulsory by empirical rules, but emerges from the individuals' behavioral decisions based on a fitness-related decision rule (Grimm \& Railsback, 2005). This approach thereby enables policy makers to make evidence-based decisions in a more relatively reasonable and efficient way.

The second paper spotlighted that the effect of human disturbance (e.g. increased bird watchers) on migrant birds is a preservation concern of global importance, as it plays an essential role determining if disruption has long-term population effects. The research is taken on Delaware Bay, the largest concentration of shorebirds in the continental USA, where thousands of shorebirds migrate here during a four-week period each spring (Clark et al., 1993; Burger et al., 1997). Data are collected from the year of 1982 to 2002, which refer to the interactions between shorebirds and people and examine tendencies in human disruptions and shorebird behavior during this time. They found potential predators and competition from laughing gulls (Larus atricilla) (Burger \& Gochfeld, 1991) pose a problem for the foraging shorebirds, direct human disturbances and declines in horseshoe crab eggs are the primary conservation issues (Burger \& Gochfeld, 1991; Burger et al., 1995).

\section{Discussion of the Problem}

The implementation of management strategies, control between connections in shore-nesting birds need to be well-understood to ensure effective and sustainable management. It is well known that human activity has the potential to negatively affect shorebirds (Burger, 1994; Thomas et al., 2003). Weather can be harsh and nests can be flooded by storms or extreme tides (Paton et al., 2000). In addition, water salinization is a particularly insidious threat to shorebird population (Rubega \& Robinson, 1996). Add to this the human brought changes of coastal development and beach stabilization, and the birds were suffering from a tough time indeed (Jan, 1992). From what illustrated above, various unstable and specific clues indicate that a number of shorebirds are facing the challenge of survival and preservation of shore-nesting birds should be carried out according to utility, sustainability and practicality. Undeniably, it is essential to set up appropriate models to study the mechanisms whereby disturbance influences behavior and fitness (West et al., 2002; Goss-Custard et al., 2006), particularly reproductive fitness (Gotmark, 1992). Katrina has also highlighted that the use of management techniques at each site needs careful examination to make sure if changes in the way that corresponding conservational program is undertaken, or the data are collected can further benefit breeding success of these species at certain sites (Katrina, 2005).

\section{Critique in Different Methodologies and Investigations}

These two studies approach the problem of understanding breeding conditions and methods from diverse perspectives. Studies by Richard et al. (2009) and Joanna et al. (2004) show the effects of different disturbances may have on breeding efficiency and methods of management through completing a comparison study using different models. In Richard's research, individual-based model approach is regarded as a worthwhile contribution to the general problem of how to improve ecology to predict that how populations of shorebirds respond to environmental change could be made. For example, their first individual-based model was for oystercatchers (Haematopus ostralegus) and correctly predicted their density-dependent mortality (Sutherland, 2006; Sutherland \& Norris, 2002). This review mainly focuses on the wider applicability of the method, and ascertains other systems to which it could be applied. They have been used to predict the effect on survival in coastal birds of sea level rise, habitat loss, wind farm development, shell fishing and human disturbance (Richard et al., 2009).

The experimental design integrated by Richard et al. (2009) used different models, mainly focus on individual-based models. In order to accomplish the whole system, there are some key procedures are involved. Firstly, recognize the need for individual-based ecology of coastal birds and establish an individual-based model 
of oystercatchers on the Exe estuary (Figure 1). As can be seen, the percentage of mortality increases steadily with the growth of density on mussel beds (Figure 1). The result clearly shows that such model predicted mortality would be density dependent, which provides validation of the approach for analyzing and applying it to other shorebirds and systems, include testing the predictions of coastal bird individual-based models according to their behavior and body condition (Goss-Custard, 1993). In the end, use individual-based models to advise coastal bird conservation.

(A)

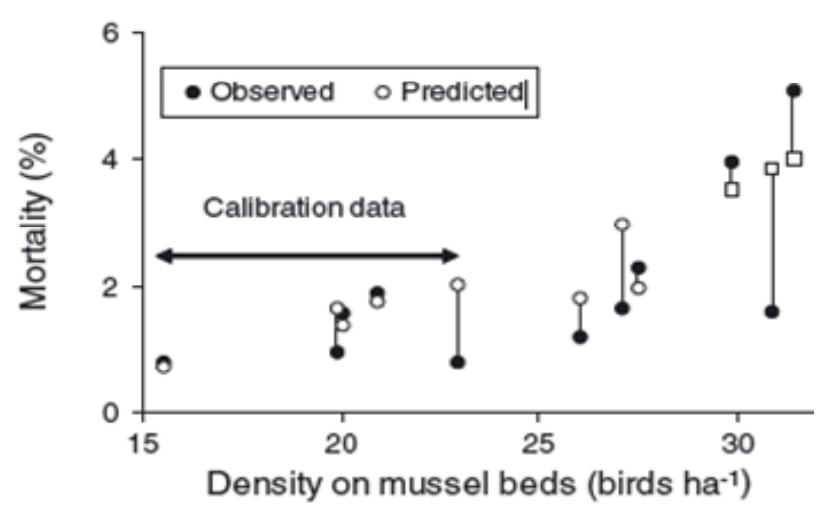

(B)

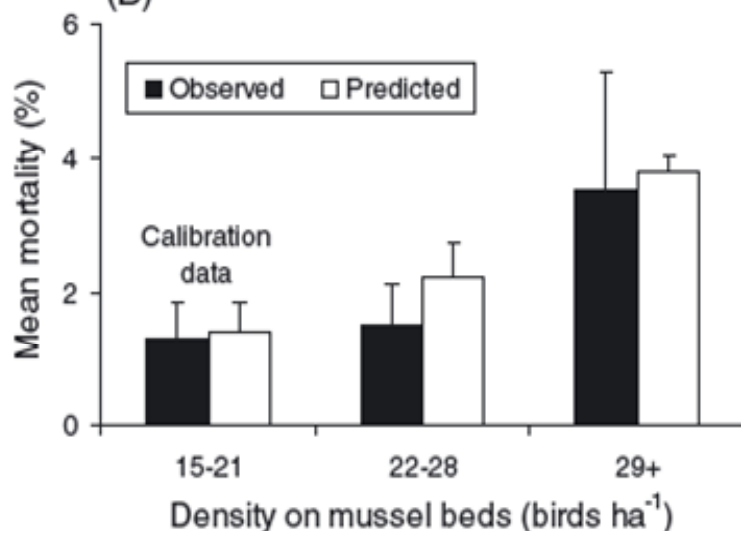

Figure 1. Predicted and observed overwinter mortality rates of adult oystercatchers on the Exe estuary over 11 winters during 1976-91: (A) year-specific comparisons; (B) comparisons within different population density classes. The resources adapted from Stillman et al. $(2000 c)$

Moreover, Richard estimated that population size and demographic rates, density dependence, and population consequences of small increases in mortality are the quantitative predictions needed to preserve and manage shore-nesting birds (Richard et al., 2009). Individual-based ecology has provided a valuable conceptual framework for making these predictions for coastal birds (Gill et al., 1996). Gill et al. also proved that conservation objectives for non-breeding shorebirds are determined from their population size at coastal sites (Gill, Watkinson, \& Sutherland, 1997; Goss-Custard, 1993).

In contrast, in Joanna's study, they made their observations at Reed's Beach North and South on the New Jersey side of Delaware Bay in 1982, 1987, 1992 and 2002 (Table 1). It has been stated the relationship between human disruptions and ecological consequences bears inspection because such a relationship is usually only inferred (Joanna et al., 2004). According to the result from Table 1, it is clear that the total number of disruptions per hour increased slightly during the $1980 \mathrm{~s}$, but had declined sharply by 2002 for Reed's Beach (two-tailed $\mathrm{t}=4.5$, $p<0.001)$.

Table 1. Frequency of shorebird disruptions as a function of management and horseshoe crab harvest. Resources came from Joanna et al. (2004)

\begin{tabular}{|c|c|c|c|c|c|}
\hline Year & $\begin{array}{l}\text { Management of bird } \\
\text { watchers }\end{array}$ & $\begin{array}{l}\text { Horseshoe crab harvest } \\
\text { and management }\end{array}$ & $\begin{array}{l}\text { Mean disruption } \\
\text { rate }\left(h r^{-1}\right)\end{array}$ & $\begin{array}{l}\% \text { Bird watchers } \\
\text { disrupting birds }\end{array}$ & $\begin{array}{l}\text { Mean time disturbed } \\
\left(\min h r^{-1}\right)\end{array}$ \\
\hline 1982 & None & Unlimited take & 4.7 & 2 & 32.9 \\
\hline 1987 & $\begin{array}{l}\text { Restrictive signs, } \\
\text { no enforcement }\end{array}$ & Unlimited take & 5.6 & 30 & 53.0 \\
\hline 1992 & $\begin{array}{l}\text { Viewing platform } \\
\text { on Reed's Beach, } \\
\text { no restrictions }\end{array}$ & $\begin{array}{l}\text { Unlimited take, } \\
\text { restrictions on } \\
\text { timing of take }\end{array}$ & 4.5 & 44 & 42.0 \\
\hline 2002 & $\begin{array}{l}\text { Signs, viewing platform } \\
\text { on Reed's Beach, } \\
\text { enforcement, patrols }\end{array}$ & No harvest & 0.4 & 0 & 3.6 \\
\hline
\end{tabular}


Observably, the percentage of bird watchers disrupting birds increased at a dramatic speed from two percent in 1982 to thirty percent in 1987 (Table 1). During this time, the average disruption was over 10 minutes, and shorebirds were often disturbed for over 40 minutes per hour. On the whole, this study indicates the rate of disruption caused by people increased during the 1980s, declined slightly by the early 1990s, and then sharply decreased by almost 90 percent until 2002. Furthermore, it has been suggested that response to humans is not equivalent to ecological effects (Gill et al., 1996, 2001a; 2001b). Nevertheless, relevant studies clearly show that there is a relationship between human activity on Reed's Beach and shorebird foraging (Joanna et al., 2004). During research, a prey depletion model with godwits (Limosa limosa) has been used to demonstrate that human disturbances might not have long-term ecological consequences (Gill et al., 2001a; Smart \& Gill, 2003). They suggest that when migrant shorebirds have a restricted period of time at a stopover place, with limited feeding space, behavioral disturbances during foraging have consequences with respects to needed weight gain (Smart \& Gill, 2003).

Moreover, as shorebirds on Delaware Bay generally feed on horseshoe crab eggs (Clark et al., 1993), the management implications are clear. It has been estimated that horseshoe crab eggs make up $50-90 \%$ of the diet of all the migrant shorebirds on Delaware Bay (Tsipoura \& Burger, 1999). Since there is a decline in the availability of eggs for foraging shorebirds (Botton \& Loveland, 2000), it is necessary to reduce human activity as much as possible so that the birds can have sufficient time to obtain enough horseshoe crab eggs to gain weight.

\section{Knowledge Gaps and Limitations of Research}

In particular, the two papers propose in the discussion so as to understand the mechanisms which affect the habitat and survival of shore-nesting birds. These methods have been proven that there is a strong relationship between human activity and shorebird foraging. The use of systematic review methodology by both papers was to specifically synthesize available information on the impact of limit disruptions to foraging shorebirds during critical migratory stopovers, and in Richard et al. (2009) different models have been involved. Although several findings are demonstrated above, there are still certain limitations ought to be kept in mind. Whilst Joanna et al (2004) could not enforce completely at all beaches as concern for declining shorebird numbers, many of the beaches are closed to human activity during the migratory season. In addition, it was demanding to validate independently the outcome of the survey, because relatively few empirical studies had been conducted on disturbance for the study species and there are some unstable elements (e.g. weather, topography) exist during research (Burger et al., 1997). In light of the management strategies, Richard et al (2009) consider how well simple models can represent the essential variables and processes required to make the quantitative predictions for population size (Gill et al., 2001b). Subjectively, however, the survey appeared to give similar results to those of research based on quantified costal observations (Atkinson et al., 2003), although it was not able to answer a key conservation question that how environmental change influence the size of coastal bird populations.

\section{Conclusion and Conservation}

In a nutshell, the two papers put forth in the discussion attempt to understand the mechanisms which are closely connected with their living conditions of the coastal birds. The methodology used by both papers included an individual-based model of oystercatchers on the Exe estuary and applying the Exe oystercatcher model to other shorebirds and systems for further coastal bird conservation (Richard et al., 2009). Whilst Gill et al. (1996, 2001a, 2001b) used a prey depletion model with godwits Limosa limosa to elegantly demonstrate that there was no evidence that human presence affected the prey supply at any spatial scale. However, Joanna et al. (2004) suggested that foraging situation varies depending on different conditions as shorebirds have less time to search for a migratory stopover when individual birds may be present for only four weeks, as compared to wintering activities. To conclude both papers presented studies which prove the importance of building a solid management plan or strategy to conserve shorebirds and their habitat. Effective solutions are offered that can easily be implemented to make significant improvements, for example, learn to recognize potential nesting habitat and built viewing platforms to contain eco-tourists and so on. It is to be hoped that shore-nesting birds will be eventually well-protected through continued cooperative efforts around the world.

\section{References}

Atkinson, P. W., Clark, N. A., Bell, M. C., Dare, P. J., Clark, J. A., \& Ireland, P. L. (2003). Changes in commercially fished shellfish stocks and shorebird populations in the Wash, England. Biological Conservation, 114, 127-141. http://dx.doi.org/10.1016/S0006-3207(03)00017-X

Botton, M. L., \& Loveland, R. E. (2000). Horseshoe crab eggs. Unpublished report to New Jersey Department 
of Environmental Protection, Trenton, New Jersey, USA.

Bowen, B. S., \& Kruse, A. D. (1993). Effects of grazing on nesting by upland sandpipers in south-central North Dakota. Journal of Wildlife Management, 57, 291-301. http://dx.doi.org/10.2307/3809426

Brian Harrington. (2007). Conserving Shorebirds on Department of Defense Lands. Department of Defense Partners in Flight Technical Series No. 3.

Burger, J. (1994). The effect of human disturbance on foraging behaviour and habitat use in piping plover (Charadrius melodus). Estuaries, 17(3), 695-701. http://dx.doi.org/10.2307/1352418

Burger, J., \& Gochfeld, M. (1991). Vigilance and feeding behavior in large feeding flocks of laughing gulls, Larus atricilla, on Delaware Bay. Estuarine Coastal and Shelf Science, 32, 207-212. http://dx.doi.org/10.1016/0272-7714(91)90015-4

Burger, J., Gochfeld, M., \& Niles, L. J. (1995). Ecotourism and birds in coastal New Jersey: contrasting responses of birds, tourists, and managers. Environmental Conservation, 22, 56-65. http://dx.doi.org/10.1017/S0376892900034081

Burger, J., Niles, L. J., \& Clark, K. E. (1997). Importance of beach, mudflat and marsh habitats to migrant shorebirds on Delaware Bay. Biological Conservation, 79, 283-292. http://dx.doi.org/10.1016/S0006-3207(96)00077-8

Caughley, G., \& Gunn, A. (1996). Conservation Biology in Theory and Practice. Blackwell Science, Oxford.

Clark, K. E., Niles, L. J., \& Burger, J. (1993). Abundance and distribution of migrant shorebirds in Delaware Bay. Condor, 95, 694-705. http://dx.doi.org/10.2307/1369612

Gill, J. A., Norris, K., \& Sutherland, W. J. (2001a). Why behavioral responses may not reflect the population consequences of human disturbance. Biological Conservation, 97, 265-268. http://dx.doi.org/10.1016/S0006-3207(00)00002-1

Gill, J. A., Norris, K., \& Sutherland, W. J. (2001b). The effects of disturbance on habitat use by black-tailed godwits Limosa limosa. Journal of Applied Ecology, 38, 846-856. http://dx.doi.org/10.1046/j.1365-2664.2001.00643.x

Gill, J. A., Sutherland, W. J., \& Watkiinson, A. R. (1996). A method to quantify the effects of human disturbance on animal populations. Journal of Applied Ecology, 33, 786-792. http://dx.doi.org/10.2307/2404948

Gill, J. A., Watkinson, A. R, \& Sutherland, W. J. (1997). Causes of the redistribution of pink-footed geese. Anser brachyrhynchus in Britain. Ibis, 139, 497-503. http://dx.doi.org/10.1111/j.1474-919X.1997.tb04665.x

Goss-Custard, J. D. (1993). The effect of migration and scale on the study of bird populations: 1991 Witherby Lecture. Bird Study, 40, 81-96. http://dx.doi.org/10.1080/00063659309477133

Goss-Custard, J. D., Triplet, P., Suer, F., \& West, A. D. (2006). Critical thresholds of disturbance by people and raptors in foraging wading birds. Biol. Conserv., 127, 88-97. http://dx.doi.org/10.1016/j.biocon.2005.07.015

Gotmark, F. (1992). The effects of investigator disturbance on nesting birds. Curr. Ornithol., 9, 63-104.

Grimm, V., \& Railsback, S. F. (2005). Individual-based Modeling and Ecology. Princeton University Press, Princeton.

Haig, S. M., \& Oring, L. W. (1985). Distribution and status of the piping plover throughout the annual cycle. Journal of Field Ornithology, 56, 334-345.

Jaensch, R. P. (2009). Migratory shorebirds in western Broad Sound, central Queensland, 2008-9. Unpublished report by Wetlands International - Oceania, Brisbane, for the Fitzroy Basin Association.

Jan Eldridge. (1992). Management of Habitat for Breeding and Migrating Shorebirds in the Midwest. Bell Museum of Natural History University of Minnesota Minneapolis, MN 55455.

Joanna Burger, Christian Jeitner, Kathleen Clark and Lawrence J. Niles. (2004). The effect of human activities on migrant shorebirds: successful adaptive management. Environmental Conservation, 31(4), 283-288. http://dx.doi.org/10.1017/S0376892904001626

Katrina Hansen. (2005). Protection of shorebirds at three Northland breeding sites-Mangawhai, Waipu, and Ruakaka. Department of Conservation. PO Box 10-420 Wellington, New Zealand.

Koenen, M. T., Jr. Leslie, D. M., \& Gregory, M. (1996). Habitat changes and nest success of artificial nests on 
an alkaline flat. Wilson Bulletin, 108, 292-301.

Lawton, J. H., \& May, R. M. (1995). Extinction Rates. Oxford University Press, Oxford, United Kingdom.

Paton, D., Ziembicki, M., Owen, P., \& Heddle, C. (2000). Disturbance distances for water birds and the management of human recreation with special reference to the Coorong region of South Australia. Stilt, 37, 46.

Paul, M., \& Dan, L. (2003). Potential Impacts to Black Oystercatchers and Other Shore-nesting Birds from Recreational Increases in Prince William Sound. USDA Forest Service, Cordova Ranger District, PO Box 280, Cordova, AK 99574.

Railsback, S. (2001). Concepts from complex adaptive systems as a framework for individual-based modelling. Ecological Modelling, 139, 47-62. http://dx.doi.org/10.1016/S0304-3800(01)00228-9

Richard, A. S., \& John, D. G. (2009). Individual-based ecology of coastal birds. Biological Reviews, 85(2010), 413-434. Cambridge Philosophical Society. http://dx.doi.org/10.1111/j.1469-185X.2009.00106.x

Robinson, J. A. L., Oring, W., Skompa, J. P., \& Boettcher, R. (1997). American avocet (Recurvirostra americana). In The Birds of North America, No. 275.

Rubega, M. A., \& Robinson, J. A. (1996). Water salinization and shorebirds emerging issues. International Wader Studies, 9, 45-54.

Silke, N., John, L. P., \& Richard, T. K. (2008). Long-term trends of shorebird populations in eastern Australia and impacts of freshwater extraction. Biological Conservation, 141, 971-980. http://dx.doi.org/10.1016/j.biocon.2008.01.017

Smart, J., \& Gill, J. A. (2003). Non-intertidal habitat use by shorebirds: a reflection of inadequate intertidal resources? Biological Conservation, 111, 359-369. http://dx.doi.org/10.1016/S0006-3207(02)00304-X

Stillman, R. A., Goss-Custard, J. D., West, A. D., Durell, S. E., Caldow, R. W. G., McGrorty, S., \& Clarke, R. T. $(2000 \mathrm{c})$. Predicting mortality in novel environments: tests and sensitivity of a behaviour-based model. Journal of Applied Ecology, 37, 564-588. http://dx.doi.org/10.1046/j.1365-2664.2000.00506.x

Strand, E., Huse, G., \& Giske, J. (2002). Artificial evolution of life history and behavior. American Naturalist, 159, 624-644. http://dx.doi.org/10.1086/339997

Sutherland, W. J., \& Norris, K. (2002). Behavioural models of population growth rates: implications for conservation and prediction. Philosophical Transactions of the Royal Society of London Series. B-Biological Sciences, 357, 1273-1284. http://dx.doi.org/10.1098/rstb.2002.1127

Thomas, K., Kvitek, R. G., \& Bretz, C. (2003). Effects of human activity on the foraging behavior of sanderlings calidris alba. Biological Conservation, 109, 67-71. http://dx.doi.org/10.1016/S0006-3207(02)00137-4

Tsipoura, N., \& Burger, J. (1999). Shorebird diet during spring migration stopover on Delaware Bay. Condor, 101, 635-644. http://dx.doi.org/10.2307/1370193

Warriner, J. S., Warriner, J. C., Page, G. W., \& Stenzel, L. E. (1986). Mating system and reproductive success of a small population of polygamous snowy plovers. Wilson Bulletin, 98, 15-37.

West, A. D., Goss-Custard, J. D., Stillman, R. A., Caldow, R. W. G., le V. dit Durell, S. E. A., \& McGrorty, S. (2002). Predicting the impacts of disturbance on shorebird mortality using a behaviour-based model. Biol. Conserv., 106, 319-328. http://dx.doi.org/10.1016/S0006-3207(01)00257-9 